\title{
n-Alkane Profile of Argemone mexicana Leaves
}

Indranil Bhattacharjee ${ }^{\mathrm{a}}$, Anupam Ghosh ${ }^{\mathrm{a}}$, Nandita Chowdhury ${ }^{\mathrm{a}}$, Soroj Kumar Chatterjee ${ }^{\mathrm{a}}$, Goutam Chandra ${ }^{\mathrm{a}, *}$, and Subrata Laskar ${ }^{\mathrm{b}}$

a Microbiology Research Unit, Parasitology Laboratory, Department of Zoology, The University of Burdwan, Burdwan-713104, West Bengal, India.

E-mail: goutamchandra63@yahoo.co.in

b Natural Product Laboratory, Department of Chemistry, The University of Burdwan, Burdwan-713104, West Bengal, India

* Author for correspondence and reprint requests

Z. Naturforsch. 65 c, 533-536 (2010); received March 1/April 16, 2010

An $n$-hexane extract of fresh, mature leaves of Argemone mexicana (Papaveraceae), containing thin-layer epicuticular waxes, has been analysed for the first time by TLC, IR and GLC using standard hydrocarbons. Seventeen long-chain alkanes $\left(n-\mathrm{C}_{18}\right.$ to $\left.n-\mathrm{C}_{34}\right)$ were identified and quantified. Nonacosane $\left(n-\mathrm{C}_{29}\right)$ was established as the $n$-alkane with the highest amount, whilst octadecane $\left(n-\mathrm{C}_{18}\right)$ was the least abundant component of the extracted wax fraction. The carbon preference index (CPI) calculated for the hydrocarbon sample with the chain lengths between $\mathrm{C}_{18}$ and $\mathrm{C}_{34}$ was 1.2469 , showing an odd to even carbon number predominance.

Key words: Alkane, Epicuticular Wax, Carbon Preference Index

\section{Introduction}

Protecting coats, so-called waxes, present on the surface of plant parts have an almost universal occurrence. Their main functions are to protect plants from physical damage and, especially from the loss of water (Schoonhoven et al., 1998), with long-chain hydrocarbons/alkanes and their derivatives present as principle chemical constituents (Baker, 1982). Alkanes from epicuticular waxes are used as indicators of taxonomic relations between plant species, and now attention has been directed towards the possibility of using their distribution as a means of establishing a chemotaxonomic system.

Argemone mexicana L. (Papaveraceae), commonly known as prickly poppy, is a common medicinal plant. The antibacterial potential of an alcoholic and aqueous extract of the plant leaves has been documented by Bhattacharjee et al. (2006). The petroleum ether extract of the plant exhibited larvicidal activity against laboratory-colonized and field-collected Culex quinquefasciatus larvae (Karmegam et al., 1997). But neither the chemical composition nor the concentration of aliphatic compounds present in the thin-layer epicuticular wax of this plant have been determined so far. The aim of the present paper was to isolate only the alkane fraction by application of a nonpolar solvent (hexane) and to characterize the $n$-alkane profile of the epicuticular waxes of leaves of this plant by gas liquid chromatography (GLC).

\section{Material and Methods}

\section{Wax extraction}

Fresh, mature leaves of $A$. mexicana were harvested randomly during July 2008 from plants growing in the surroundings of Department of Zoology, University of Burdwan, India. $50 \mathrm{~g}$ freshly collected mature leaves of A. mexicana were rinsed with distilled water and dried on paper towelling. Leaves were then dipped in $2 \mathrm{~L}$ of cold $n$-hexane for $45 \mathrm{~min}$, and surface wax was extracted at room temperature. The crude extract was filtered through Whatman filter paper no. 41 (Whatman, Maidstone, UK), and the solvent was removed under reduced pressure. The extract was then fractionated by preparative thin-layer chromatography (TLC) using carbon tetrachloride as mobile phase. The thin-layer chromatographic plates (thickness of $0.5 \mathrm{~mm}$ ) were prepared with silica gel G (Merck, Mumbai, India) using a Unoplan coating apparatus (Shandon, London, UK). The single hydrocarbon band was identified through co-TLC studies with standard samples 
(Sigma, St. Louis, MO, USA). The band was eluted from the layer with chloroform; it showed no absorption of any detectable functional group in the infrared region. The presence of alkanes was further confirmed by argentometric TLC.

\section{GLC analysis of surface wax}

The purified hydrocarbon fraction was analysed directly by GLC on a Hewlett Packard (Palo Alto, CA, USA) model 5890 series II instrument fitted with an HP-1 capillary column $(25 \mathrm{~m}$ $\times 0.01 \mathrm{~mm}$ internal diameter) and a flame ionization detector; nitrogen was used as carrier gas at a flow rate of $16.5 \mathrm{~mL} / \mathrm{min}$. Oven temperature was $170-300{ }^{\circ} \mathrm{C}$ at a $5{ }^{\circ} \mathrm{C} / \mathrm{min}$ rise, initial period was $1 \mathrm{~min}$, and the final period was $15 \mathrm{~min}$. Com- ponents were characterized through co-TLC with authentic samples of $n$-alkanes (Sigma).

All solvents employed were of analytical grade and obtained from Merck (Mumbai, India).

\section{Results and Discussion}

Fig. 1 shows the GLC separation of the hydrocarbons of the $n$-hexane extract of the epicuticular wax of mature leaves of $A$. mexicana. Seventeen long-chain alkanes $\left(n-\mathrm{C}_{18}\right.$ to $\left.n-\mathrm{C}_{34}\right)$ were identified and quantified. The carbon preference index (CPI) calculated for the hydrocarbon sample with the chain lengths between $\mathrm{C}_{18}$ and $\mathrm{C}_{34}$ was 1.2469 , showing an odd to even carbon number predominance.

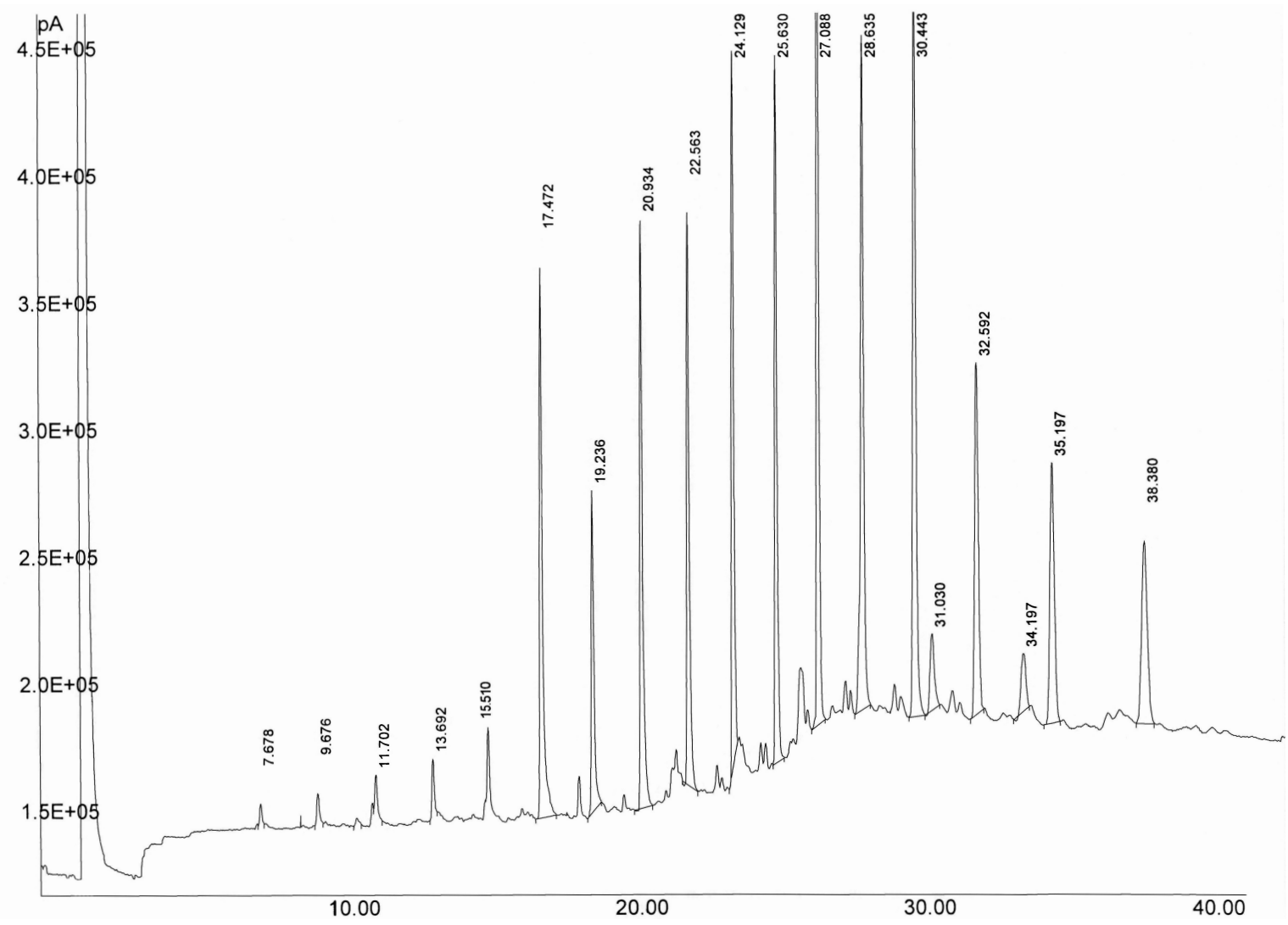

Fig. 1. Gas liquid chromatogram of the $n$-hexane extract of fresh, mature leaves of $A$. mexicana. 
The surfaces of leaves, flowers, fruits, and nonwoody stems are covered by a cuticle made of cutin and waxes (Jetter et al., 2006). Among the cuticular wax layer, an intracuticular and an epicuticular layer can be distinguished according to the wax location inside the cutin matrix and exterior to it, respectively (Jeffree, 1986). Epicuticular waxes serve many physiological functions, including protection against UV light (Reicosky and Hanover, 1978) and moderation of gas exchange through stomata (Jeffree et al., 1971). Besides, the epicuticular waxes form the true surface of the plant organs and, therefore, play an important ecological role in the interaction with insects (Müller, 2006) and pathogens (Carver and Gurr, 2006). There are significant differences in the individual and total $n$-alkane concentrations in plant leaves (Jetter et al., 2000; Piasentier et al., 2000; Barik et al., 2004; Jetter and Schäffer, 2001). Higher alkanes are known to be one of the main components of cuticular waxes of plant leaves and stems. Moreover, in the homologous series the hydrocarbon fraction with an odd number of carbon atoms predominates considerably (Isidorov and Vinogorova, 2003; Buschhaus et al., 2007). Further, Hellmann and Stoesser (1992), Dutton et al. (2000), and Piasentier et al. (2000) reported that heptacosane $\left(n-\mathrm{C}_{27}\right)$, hentriacontane $\left(n-\mathrm{C}_{31}\right)$, and tritriacontane $\left(n-\mathrm{C}_{33}\right)$ were the most prominent alkanes present in the epicuticular wax. However, our study produced different results as nonacosane $\left(n-\mathrm{C}_{29}\right)$ was established as the

Baker E. A. (1982), Chemistry and morphology of plant epicuticular waxes. In: The Plant Cuticle (Cutler D. F., Alvin K. L., and Price C. E., eds.). Academic Press, London, pp. 139-165.

Barik A., Bhattacharya B., Laskar S., and Banerjee T. C. (2004), The determination of $n$-alkanes in the cuticular wax of leaves of Ludwigia adscendens L. Phytochem. Anal. 15, 109-111.

Bhattacharjee I., Chatterjee S. K., Chatterjee S. N., and Chandra G. (2006), Antibacterial potentiality of Argemone mexicana solvent extracts against some pathogenic bacteria. Mem. Inst. Oswaldo Cruz. 101, 645-648.

Buschhaus C., Herz H., and Jetter R. (2007), Chemical composition of the epicuticular and intracuticular wax layers on adaxial sides of Rosa canina leaves. Ann. Bot. 100, 1557-1564.
Table I. Distribution of $n$-alkane constituents in the $n$ hexane extract of mature leaves of $A$. mexicana.

\begin{tabular}{cllcr}
\hline Peak & Compound & & $\begin{array}{l}\text { Retention } \\
\text { time [min] }\end{array}$ & $\begin{array}{r}\text { Amount } \\
(\mathrm{mol} \%)\end{array}$ \\
\hline 1 & Octadecane & $\left(n-\mathrm{C}_{18}\right)$ & 7.678 & 1.2080 \\
2 & Nonadecane & $\left(n-\mathrm{C}_{19}\right)$ & 9.676 & 1.4770 \\
3 & Eicosane & $\left(n-\mathrm{C}_{20}\right)$ & 11.702 & 1.6337 \\
4 & Heneicosane & $\left(n-\mathrm{C}_{21}\right)$ & 13.692 & 2.2129 \\
5 & Docosane & $\left(n-\mathrm{C}_{22}\right)$ & 15.510 & 1.0270 \\
6 & Tricosane & $\left(n-\mathrm{C}_{23}\right)$ & 17.472 & 7.1622 \\
7 & Tetracosane & $\left(n-\mathrm{C}_{24}\right)$ & 19.236 & 3.8396 \\
8 & Pentacosane & $\left(n-\mathrm{C}_{25}\right)$ & 20.934 & 6.9558 \\
9 & Hexacosane & $\left(n-\mathrm{C}_{26}\right)$ & 22.563 & 6.4799 \\
10 & Heptacosane & $\left(n-\mathrm{C}_{27}\right)$ & 24.129 & 7.4189 \\
11 & Octacosane & $\left(n-\mathrm{C}_{28}\right)$ & 25.630 & 7.5132 \\
12 & Nonacosane & $\left(n-\mathrm{C}_{29}\right)$ & 27.088 & 10.6814 \\
13 & Triacontane & $\left(n-\mathrm{C}_{30}\right)$ & 28.635 & 9.4555 \\
14 & Hentriacontane & $\left(n-\mathrm{C}_{31}\right)$ & 30.443 & 10.4134 \\
15 & Dotriacontane & $\left(n-\mathrm{C}_{32}\right)$ & 32.592 & 5.8923 \\
16 & Tritriacontane & $\left(n-\mathrm{C}_{33}\right)$ & 35.197 & 5.2423 \\
17 & Tetratriacontane $\left(n-\mathrm{C}_{34}\right)$ & 38.380 & 4.8462 \\
\hline
\end{tabular}

$n$-alkane with highest amount, whilst octadecane $\left(n-\mathrm{C}_{18}\right)$ was the least abundant (Table I).

In conclusion, $A$. mexicana is a medicinal plant with established antimicrobial and mosquitolarvicidal property found in different parts of the world. The extraction of epicuticular wax by a nonpolar solvent made it possible to broaden greatly the list of compounds detected previously. This analysis also provides a basis for further research on interactions between leave surfaces of this plant and insect herbivores or pathogenic microorganisms.
Carver T. L. W. and Gurr S. J. (2006), Filamentous fungi on plant surfaces. In: Biology of the Plant Cuticle (Riederer M. and Müller C., eds.). Blackwell Publishing, London, pp. 368-397.

Dutton A., Mattiacci L., and Dorn S. (2000), Plant derived semiochemicals as a contact host location stimuli for a parasitoid of leafminers. J. Chem. Ecol. 26, 2259-2273.

Hellmann M. and Stoesser R. (1992), Seasonal ontogenic and variety specific changes of the surface wax from apple leaves. Angew. Bot. 66, 109-114.

Isidorov V. A. and Vinogorova V. T. (2003), GC-MS analysis of compounds extracted from buds of Populus balsamifera and Populus nigra. Z. Naturforsch. 58c, $355-360$.

Jeffree C. E. (1986), The cuticle, epicuticular waxes and trichomes of plants, with reference to their structure, 
functions and evolution. In: Insects and the Plant Surface (Juniper B. and Southwood R., eds.). Edward Arnold, London, pp. 23-135.

Jeffree C. E., Johnson R. P. C., and Jarvis P. G. (1971), Epicuticular wax in the stomatal antechamber of sitka spruce and its effects on the diffusion of water vapour and carbon dioxide. Planta 98, 1-10.

Jetter R. and Schäffer S. (2001), Chemical composition of the Prunus laurocerasus leaf surface. Dynamic changes of the epicuticular wax film during leaf development. Plant Physiol. 126, 1725-1737.

Jetter R., Schäffer S., and Riederer M. (2000), Leaf cuticular waxes are arranged in chemically and mechanically distinct layers: evidence from Prunus laurocerasus L. Plant Cell Environ. 23, 619-628.

Jetter R., Kunst L., and Samuels A. L. (2006), Composition of plant cuticular waxes. In: Biology of the Plant Cuticle (Riederer M. and Müller C., eds.). Blackwell Publishing, London, pp. 182-215.
Karmegam N., Sakthivadivel M., Anuradha V., and Daniel T. (1997), Indigenous plant extracts as larvicidal agents against Culex quinquefasciatus Say. Bioresour. Technol. 59, 137-140.

Müller C. (2006), Plant insect interactions on cuticular surfaces. In: Biology of the Plant Cuticle (Riederer M. and Müller C., eds.). Blackwell Publishing, London, pp. 398-422.

Piasentier E., Bovolenta S., and Malossini F. (2000), The $n$-alkane concentration in buds and leaves of browsed broad leaf tree. J. Agric. Sci. 135, 311-320.

Reicosky D. A. and Hanover J. W. (1978), Physiological effects of surface waxes I. Light reflectance for glaucous and nonglaucous Picea pungens. Plant Physiol. 62, $101-104$.

Schoonhoven L. M., Jeremy T., and van Loon J. J. A. (1998), Insect-Plant Biology: from Physiology to Evolution. Chapman \& Hall, London, pp. 31-82. 